\title{
The response of mineral chronometers to metamorphism and deformation in orogenic belts.
}

\author{
Randall R Parrish \\ Department of Geology, University of Leicester \\ NERC Isotope Geoscience Laboratories \\ British Geological Survey \\ Keyworth, Notts, NG12 5GG \\ United Kingdom \\ r.parrish@nigl.nerc.ac.uk
}

\begin{abstract}
Mineral chronometers, especially accessory minerals using the U-Pb decay system, can reveal important information regarding the environmental conditions and duration of metamorphic-deformation events during the re-working of older rocks. Minerals such as zircon can newly grow during amphibolite facies or granulite facies events, providing direct ages of metamorphism. Pre-existing minerals like monazite, allanite, and titanite can preserve a component of their original age in spite of upper amphibolite facies re-working and very thorough recrystallisation of the rock fabric during mylonite development. The degree of incomplete $\mathrm{Pb}$ loss can be used to deduce, at least semi-quantitatively, the temperature and duration of the subsequent event. In well-studied examples, the relative retentivity of $\mathrm{Pb}$ is highly predictable, and this helps place strong constraints on relative closure temperatures, even when laboratory experimental data are lacking or inconclusive. A number of examples are presented from a wide variety of geological environments to illustrate the response of $\mathrm{U}-\mathrm{Pb}$ isotope systematics within accessory minerals superimposed deformation, metamorphism and/or mineral growth.
\end{abstract}




\section{Introduction}

The response of mineral isotope systematics to metamorphism and deformation refers to how pre-existing minerals are affected by new environmental conditions, and to how this response can be used to infer quantitative aspects such as temperature, timing and duration of a subsequent event. This paper reviews this topic as it pertains to the reactivation and reworking of older terrains within orogenic belts.

Although various isotopic systems have been applied to the cooling history and dating of rocks, this paper emphasizes the U-Pb scheme with accessory minerals because of their widespread application to Precambrian rocks. U-Pb geochronology has developed in the past 20 years into one of the most important geological tools and has revolutionized the interpretation of Precambrian orogens and their temporal evolution. One of the most important legacies of $\mathrm{U}-\mathrm{Pb}$ dating using both conventional isotope dilution thermal ionisation mass spectrometry (TIMS) and secondary ionisation mass spectrometry (SIMS, especially SHRIMP; Compston et al. 1984; Stern 1999) has been the extraction of primary crystallisation ages of igneous protoliths from complexly deformed and metamorphosed lithologies. The importance of this geological information is plain to see. For example, these type of studies have revealed the age of the world's oldest rocks in the Acasta gneisses of the western Slave Province (Bowring \& Williams 1999) that would otherwise have been indeterminate with any degree of precision. The ability of zircon to withstand the battering of multiple high grade metamorphic events and retain the signature of its original crystallisation is well known. This is perhaps its most valuable aspect to earth scientists.

By contrast, the application of U-Pb dating using minerals other than zircon was slower to enter the mainstream. These alternative minerals can reveal the thermal and deformational history of complex orogenic belts. Minerals that either recrystallize or lose some or all of their radiogenic $\mathrm{Pb}$ during metamorphic-deformational events are 
the most important minerals to be employed in reconstructing the chronology of the thermal-metamorphic history.

The relevance of the $\mathrm{U}-\mathrm{Pb}$ system in relation to other dating systems (i.e. $\mathrm{K}-\mathrm{Ar}, \mathrm{Rb}$ $\mathrm{Sr}$ ) lies in three important facts. First, the accessory minerals datable by the $\mathrm{U}-\mathrm{Pb}$ method have quite variable $\mathrm{Pb}$ retentivities, allowing them to be used over a wide range of conditions. Second, many of these minerals have significant enrichment of uranium coupled with little or no incorporation of initial lead, leading to a more robust interpretation, and the dating can be undertaken with one mineral using single grain or intra-grain analysis. Third, the coupled decay scheme of two uranium parent isotopes decaying to two different radiogenic lead isotopes potentially allows no loss of precision across the entire spectrum of geological time with about one million year resolution. A drawback however, is the difficulty in relating the growth of accessory minerals to the development of specific textures or mineral reactions with P-T significance.

Many of the accessory minerals used in U-Pb geochronology, such as zircon, titanite, monazite, xenotime, rutile, apatite, and allanite are involved in metamorphic reactions with other minerals including garnet, clinopyroxene, amphibole, plagioclase, etc. Although the pressure-temperature-fluid conditions of such reactions are at present very poorly understood, there is great potential to coordinate the isotopic and P-T data into a robust P-T-time path which could improve significantly the interpretation of calculated ages. This in turn would quantifiably improve knowledge of the response of pre-existing datable minerals to subsequent tectonic events.

This paper will introduce the main elements that govern how these mineral chronometers respond to subsequent events, present several illustrative examples, and discuss the metamorphic petrology of accessory minerals that have undergone recrystallisation during reworking, relating dating to mineral-forming reactions. 


\section{Processes affecting the isotopic response in mineral chronometers}

\section{Mineral cooling and closure temperature}

The literature on the theoretical, experimental, and empirical aspects of closure temperature in minerals is well-developed, having its origins in the work of Armstrong (1966). In that study of orogenic belts, widespread re-setting of K-Ar ages by subsequent re-heating and metamorphism was clearly documented. The theory of radiogenic isotope retention in cooling rocks was elegantly quantified by Dodson (1973), whose name is synonymous with closure temperature. This concept is now widely applied to reveal aspects of the thermal history of cooling orogens. Provided that minerals cooled from temperatures where there was no retention of radiogenic daughter isotope to temperatures where complete retention prevailed, the approach is generally valid. Taking advantage of the variable closure temperatures of a variety of minerals using several analytical methods, it is possible to determine the cooling history of a terrain over more than $600^{\circ} \mathrm{C}$. Figure 1 is an example from British Columbia of a relatively complete thermal history using this approach (Spear \& Parrish 1996), using dating schemes discussed further in this paper.

\section{Relative retentivities of radiogenic daughter isotopes in minerals}

Many studies, both experimental and empirical, have helped to elucidate the approximate closure temperatures of minerals used in thermochronology. Table 1 summarizes this body of knowledge. The closure temperature of some minerals is entirely within the brittle field of deformation (i.e. fission track dates in apatite), whereas that of other minerals are within middle to upper amphibolite facies conditions where metamorphic recrystallisation leading to ductile flow is common (i.e. titanite $\mathrm{U}-\mathrm{Pb}$ ). The value and relevance of mineral chronometers to revealing conditions of orogenic reworking is therefore quite variable.

\section{The isotopic response of minerals to heating}

In reworked terrains, incomplete loss of radiogenic isotopes (i.e. partial re-setting) during a heating event is common, and in these circumstances, the theory is less well 
developed with few well-studied examples. Examples are the presence of complex argon release spectra in hornblende, mica or feldspar (McDougall \& Harrison 1988), complex $\mathrm{Rb}-\mathrm{Sr}$ mineral isochrons, discordance in $\mathrm{U}-\mathrm{Pb}$ dates, and inherited xenocrystic zircon in anatectic magma.

In an influential early study by Hart (1964), the pattern of age re-setting in Precambrian gneisses in Colorado as a function of distance from the Tertiary Eldora stock was well documented. Hornblende K-Ar dates were fully reset only within a few metres of the contact whereas biotite K-Ar dates reflected the age of intrusion up to $100 \mathrm{~m}$ away from granite-gneiss boundary. This study was one of the first to establish the relative retentivities of radiogenic $\mathrm{Sr}$ and $\mathrm{Ar}$ in minerals. From this type of study it is possible to calculate the fractional loss of radiogenic daughter isotope that occurred during heating. Using equations of diffusion (i.e. Carslaw \& Jaeger 1959), mineral diffusivities, duration of heating and effective grain size, the maximum temperature of heating can be deduced, in theory. Alternatively, if the temperature was well-constrained, the maximum duration of a heating event could be determined, which in turn could have important tectonic consequences.

\section{An integrated example of basement reheating.}

In a study from the southeastern Canadian Cordillera, Crowley (1999), Crowley and Parrish (1999), and Parrish (1995) studied the response of mineral chronometers in ca. 1.9-2.1 Ga protolith gneisses to re-heating during a 50-60 Ma event involving intracrustal thrusting. In this area high grade (sillimanite-K feldspar- anatexis) hanging wall terrain (the Selkirk Allochthon) was emplaced within a thick ductile shear zone (the Monashee decollement), onto the footwall consisting of Precambrian granitic/gneissic rocks (the Monashee Complex). The heating of the footwall was variable, with deformational and metamorphic effects decreasing downwards. Significant reworking of the footwall is present within the shear zone up to $1.0 \mathrm{~km}$ beneath the thrust, with widespread recrystallisation of quartz, feldspar, mica and amphibole. Beneath the zone of re-working, Precambrian structures can be recognised (Figure 2). 
1.86 Ga titanite, monazite, and zircon are present within amphibolite and leucogranite of the footwall. Zircon is the least well-behaved of the minerals in terms of $\mathrm{U}-\mathrm{Pb}$ systematics, due to a combination of $\mathrm{Pb}$ loss events. However, the U-Pb systematics of titanite and monazite reveal a linear array of analyses connecting ca. $1.86 \mathrm{Ga}$ with ca. 50-60 Ma (summarized in figure 3 from a much larger data set). There appears to be a correlation between $\mathrm{U}-\mathrm{Pb}$ discordance and proximity to the hanging wall, with discordance varying widely from $6 \%$ to $96 \%$. There is also limited evidence that discordance may partly be a function of grain size, but this is not simple because of partial recrystallisation. Notwithstanding the complexities of recrystallisation manifested by a coronitic zoning of apatite+thorite on original monazite, the maximum fractional loss of radiogenic $\mathrm{Pb}$ from monazite and titanite from lower structural levels during the $60 \mathrm{Ma}$ event can be broadly estimated from these analyses to be less than $30 \%$ and $65 \%$, respectively (Figure 3 ).

For the sake of argument, if one accepts that diffusion coefficients for these minerals can be estimated, even with inconsistent experimental values (Heaman \& Parrish 1991; Suzuki et al. 1994; Cherniak 1993; Smith \& Giletti 1997), a family of maximum temperature and heating duration combinations can produce the documented fractional loss, for the grain sizes of minerals that were analysed. Using maximum temperatures derived from petrological arguments (i.e. $600^{\circ} \mathrm{C}-700^{\circ} \mathrm{C}$ ), the duration of heating can be deduced. This analysis was done as part of the Parrish (1995) and Crowley and Parrish (1999) studies; these heating duration estimates were much shorter than intuitively expected, generally a maximum of 2 million years. Because the shear zone has displacement exceeding $100 \mathrm{~km}$, relatively rapid rates of emplacement are implied. Although this analysis has limitations due to uncertain input parameters, it indicates the potential of the approach in providing a quantitative estimate of heating rates, that in turn provide constraints on the rates of movement and strain in shear zones. This information was extracted mainly from mineral chronometers in the reworked older gneisses. By contrast, mineral dates on all hanging wall minerals other than zircon are Cretaceous or younger and these provide no particular insight into the conditions prevailing in the reworked footwall rocks. This example establishes how the thermal history, including inferences about the 
duration of events, can be deduced by the response of minerals to orogenic re-heating during reworking.

\section{Armouring of minerals: isotopic effects}

The diffusion of radiogenic isotopes from mineral to matrix occurs when the mineral's diffusivity is sufficiently high at a given temperature, provided the matrix can incorporate the diffusing element. This process becomes limited when a mineral is enclosed within another mineral of limited diffusivity, for example when armoured by garnet. Recent papers by Zhu et al. (1997) and Zhu and O’Nions (1999) documented monazite crystals within garnet, in high grade pelite of the late Archaean Lewisian basement of northwest Scotland. In these samples, monazite ages on armoured inclusions are generally older than those of the matrix, by up to $200 \mathrm{Ma}$ or more. This example illustrates how a protracted metamorphic history may be extracted from a single thin section. The metamorphic reaction(s) that caused primary growth of metamorphic monazite, and the associated pressure-temperature-fluid environment, are however, less clear.

\section{Consequences of metamorphism and recrystallisation to isotope systematics}

When older rocks are reworked by a subsequent event, there is an imposition of new environmental conditions. These comprise different pressure and temperature, and the introduction of a fluid phase into an otherwise relatively dry rock. Variable strain is also imposed, a condition favouring neoblast growth and variable recrystallisation of pre-existing mineral phases. The new environmental conditions can result in prograde metamorphism of the older rocks, for example heating mafic lithologies to eclogite or granulite facies. Also encountered in orogenic belts is the retrogressive effect of reworking of granitic rocks with a pre-existing high temperature igneous mineralogy. Fabrics associated with the younger event are often penetrative and characterised by mineralogy consistent with the superimposed conditions. 


\section{Prograde reworking: eclogite and granulite development}

High pressure and high temperature metamorphism of reworked basement is a common feature of collisional orogens when subduction of continental crust occurs. Metamorphic zircon is a common feature of certain lithologies, mainly mafic rocks, and it provides an excellent means to date the metamorphic event (Davidson \& van Breemen 1988; Figure 4a, 5a,c).

The Norwegian Caledonides contain a world class example of this type where footwall gneisses of Mesoproterozoic age were overthrust by Caledonian nappes during continental collision (Gee 1978). A regional eclogite terrane was developed, manifest by the preservation of eclogite in appropriate mafic lithologies, often occurring only as boudins (Wain 1997). These older mafic rocks, of presumed preCaledonian amphibolite or lower metamorphic facies, were deformed into discontinuous sheets and boudins during shearing, with significant changes to mineralogy and texture. In adjacent $1.6 \mathrm{Ga}$ granitic gneisses, shear fabrics were superimposed but mineralogical evidence for high pressure metamorphism is less evident (Dewey et al. 1993).

In a study of the titanite occurring in the 1.6 Ga protoliths of the Norwegian Caledonides, Tucker et al. (1987) showed that a younger generation of titanite was present, in addition to older crystals, with core-rim zoning being observed. The U-Pb systematics of titanite from various samples preserved a striking linear array on the concordia diagram connecting the original titanite age $(1.66 \mathrm{Ga})$ with the $395 \mathrm{Ma}$ age of the Caledonian metamorphic event. Titanite $\mathrm{U}-\mathrm{Pb}$ systematics indicate 6-100\% discordance along this linear array. Although it is not possible to fully differentiate the effects of $\mathrm{Pb}$ loss and new growth on the isotope systematics, the age and relatively short duration of the Caledonian event was accurately determined. The tectonic events, including continental subduction, eclogite facies metamorphism, and rapid tectonic denudation and cooling, occurred rapidly (Krabbendam \& Dewey, 1998).

In a study of variably retrogressed eclogite preserved in the Lewisian Glenelg inlier of northwest Scotland, Sanders et al. (1984) determined a 1.0-1.1 Ga Sm-Nd age of 
garnet-clinopyroxene pairs, suggesting 'Grenvillian' eclogite development within host gneisses that were inferred to be $>2.5 \mathrm{Ga}$. Subsequent detailed study of one eclogite (T. S. Brewer \& others, unpublished data, 1999) revealed that metamorphic zircon occurred in these samples (Figure 4e), usually as round to irregular grains with very low uranium contents of less than 10ppm. The rare occurrence of these grains in thin section suggests that they preferentially occur within zones of hydration and retrogression. Rutile in equilibrium with the eclogite facies assemblage is partially replaced by titanite (Figure $4 \mathrm{~b}$ ) produced during retrogression. Titanite also occurs as matrix grains. An analysis of the U-Pb systematics of zircon, titanite and rutile reveals a complex picture of isotopic disequilibrium. The titanite is similar in age, within error, to the metamorphic zircon at very close to $1.00 \mathrm{Ga}$. Rutile, on the other hand, is ca. $430 \mathrm{Ma}$. The rutile age can be explained by its low $\mathrm{Pb}$ retentivity, with final closure of its $\mathrm{Pb}$ mobility in Caledonian time.

These examples show that in reworked older rocks, zircon and titanite can provide information on the age of subsequent metamorphic events during both eclogite facies and later retrogression. Careful study of the fabrics associated with these mineralogical changes may allow inferences about the absolute age of the fabric development to complement geological or regional arguments.

\section{Retrogression of granulites during reworking}

In the Ungava peninsula, northern Quebec, the Late Archaean crust of the Superior Province was over-ridden by the metasedimentary and metavolcanic allochthons of the Cape Smith Belt (St-Onge et al. 1992). The Archaean rocks beneath the basal decollement preserve evidence of both granulite and amphibolite facies metamorphism, whereas the allochthons are of greenschist to lower amphibolite facies. The zone of footwall deformation (Lucas \& St-Onge 1992) is tens to hundreds of metres thick, and is associated with hydration and metamorphic retrogression. Within granulites, titanite is absent, rutile being the stable Ti-bearing phase. Within the hornblende-bearing retrogressed zones, original orthopyroxene and rutile are rare to absent, and titanite is stable, in part overgrowing ilmenite. The retrogressive reaction(s) were probably catalysed by the presence of water. In a study of the 
isotopic response of these samples, Scott and St-Onge (1995) dated titanite from numerous samples of retrogressed granulite within this zone. The ages were nearly concordant, ranging from 1814 to $1789 \mathrm{Ma}$, and these dates were interpreted to reflect the age of titanite growth, fabric development, retrogression, and shear strain. In this case petrographic evidence of new titanite growth is very clear. A factor considered by the authors was the extent to which the titanite ages were cooling ages, since the temperatures of retrogressive metamorphism $\left(670^{\circ} \mathrm{C}\right)$ are similar to the titanite closure temperature estimate (Table 1). If the titanite dates were in fact cooling ages, then they place only a minimum constraint on the ages of the retrogression and shearing. This situation illustrates an interpretation ambiguity that shall remain until better diffusion information is obtained.

Zircon within these rocks is virtually unaffected by the Proterozoic retrogression event, and this can provide no useful information on its age. Because of the relatively low metamorphic grade, no pegmatite or other intrusive rocks are associated with the shearing, rendering the dating of the shear zone problematic. Dates using the K-Ar and ${ }^{40} \mathrm{Ar}-{ }^{39} \mathrm{Ar}$ methods on hornblende and mica are less than $1750 \mathrm{Ma}$ and they shed little light on the age of basement reworking. Titanite growth, a product of mineral reactions during shearing and associated retrogression, provides instead the most important timing constraint of shear zone development.

\section{Reworking of rocks under amphibolite facies conditions}

Hornblende - biotite bearing granitic rocks are a common granitoid type in continental crust. They are commonly involved in subsequent re-working events. If subjected to middle to upper amphibolite facies conditions during shearing and recrystallisation, the mineralogy is unlikely to change substantially, though there may be penetrative fabric development. In the re-heating and recrystallisation of these types of rocks, Fe-Mg mica and hornblende will be completely reset, losing all radiogenic argon (and $\mathrm{Sr}$ ) and will yield cooling ages if dated. Accessory minerals such as allanite, titanite, zircon and apatite may be present, and for the most part will remain stable mineralogically during middle to upper amphibolite facies re-working. Although recrystallisation of these accessory minerals does occur and is sometimes 
visible as core/rim overgrowth relationships (Tucker et al. 1987), titanite and allanite appear to have greater internal strength than most rock forming minerals. They often resist recrystallisation during penetrative fabric development, although a common feature is a partial resorption of sharp edges and surfaces of euhedral phenocyrsts to produce a rounded subhedral appearance, as illustrated by zircon in figures $5 \mathrm{~d}$ and $5 \mathrm{e}$. Sometimes, resorption can be extreme, producing highly irregular crystal shapes (Figure 5b).

In a study of ultramylonites within the Brevard zone of the Appalachians, Wayne and Sinha $(1988,1992)$ showed that zircon was little-affected by intense fracturing and by the thorough recrystallisation and grain size reduction in the rock's matrix. These studies show that little information can be obtained on the nature of the subsequent deformational event from zircon; instead, zircon clearly preserves the protolith age.

The survival of original igneous grains in spite of major recrystallisation can be proven by the $\mathrm{U}-\mathrm{Pb}$ systematics in a study of the reworking of $100 \mathrm{Ma}$ and $360 \mathrm{Ma}$ granodiorite protoliths during an upper amphibolite facies event ca. $60 \mathrm{Ma}$ ago (Figure 6; Heaman \& Parrish 1991; Spear \& Parrish 1996). In that study, allanite was found to be $75-90 \%$ discordant, but not fully reset. Titanite from the same samples was much more discordant, approximately $90-99 \%$, but still not totally reset. Aside from demonstrating survival of original grains, these data show clearly that allanite has a stronger retention of $\mathrm{Pb}$ than titanite. These discordant arrays can be used to infer both initial age of protolith (along with zircon), age of the subsequent event, and semi-quantitative information on the temperature and duration of the later event. These minerals are thus a powerful bridge between the information obtained from U$\mathrm{Pb}$ zircon on the one hand, and K-Ar or Rb-Sr mica ages on the other.

\section{Metamorphic and isotopic effects during lower temperature reworking}

During lower amphibolite and greenschist facies metamorphic conditions, granitic lithologies usually contain a mineralogy substantially modified from the protolith. For example, hornblende may react to form biotite, epidote, and/or chlorite, and relatively 
calcic plagioclase may become sausseritised with the formation of albite, epidote and calcite. With more leucocratic lithologies (mica-bearing granitoid rocks) affected by lower greenschist conditions, biotite reacts to form chlorite, or muscovite if metasomatism is significant. Because the lower temperature stability of hornblende virtually coincides with its closure temperature $\left(\mathrm{ca} .500^{\circ} \mathrm{C}\right)$, argon dating of hornblende will rarely, if ever, provide an unambiguous age of mineral growth, excepting rapidly cooled and unaltered volcanic rocks. Argon dating of mica has the same problem.

Useful isotopic information on the age of crystal growth can be extracted from $\mathrm{Rb}-\mathrm{Sr}$ dating of medium to coarse-grained muscovite. In an insightful study, Piasecki and van Breemen (1983) recognised correctly that $\mathrm{Rb}-\mathrm{Sr}$ dating of large books of muscovite, even when subjected to an amphibolite facies Caledonian event, preserved evidence of their crystallisation more than $700 \mathrm{Ma}$ ago. This can be explained by the positive correlation of grain size with closure temperature (Dodson 1973); very large muscovite books several centimetres in diameter may retain their radiogenic $\mathrm{Sr}$ to upper amphibolite facies temperatures.

The studies of Meffan-Main and Cliff (1997) and Freeman et al. (1997) in the Swiss Alps applied Rb-Sr dating to fabric-forming minerals in the re-worked Variscan granitoid basement nappes of the central Alps. They used microsampling techniques to date new mica, calcite, and feldspar that grew during the Alpine event. This work has allowed robust direct dating of Alpine deformation and has also provided an explanation of why bulk dating of mica and feldspar from similar samples have ambiguous ages that are difficult to interpret. Isotopic disequilibrium amongst the major phases, including older feldspar megacrysts, is widespread in this greenschist grade environment.

In an application to the dating of shear zone fabrics, Parrish et al. (1988) studied porphryoblastic muscovite growing in a sheared biotite granite during lower greenschist facies conditions. In this sample, biotite disappeared from the protolith upon significant ductile shearing and recrystallisation at this low grade.

Metasomatism accompanied by major fluid fluxing induced the growth of muscovite 
at the expense of biotite, with only minor formation of chlorite. Muscovite 'fish' that formed concurrently with $\mathrm{C}-\mathrm{S}$ fabric development, yielded $\mathrm{Rb}-\mathrm{Sr}$ ages calculated with feldspar that accurately reflected the age of shearing. Because the closure temperature for $\mathrm{Sr}$ diffusion in muscovite is about $500^{\circ} \mathrm{C}$, the mica grew more than $100^{\circ} \mathrm{C}$ below its closure temperature, a condition ensuring full radiogenic $\mathrm{Sr}$ retention and a robust age determination; these mica ages are shown in the thermal history of figure 1 .

\section{Allanite-monazite equilibria in retrogressed rocks}

There are several good examples of reaction textures involving allanite, monazite, apatite, and/or thorite from samples exposed to either a subsequent metamorphic event or a retrogressive metamorphism following peak temperature. Finger et al (1998), Fraser (2000), and Simpson et al. (2000) describe granitoid and/or pelitic samples that contain monazite surrounded by a complex reaction rim involving apatite, allanite, and/or thorite. This is probably a retrogressive reaction involving the addition of water, possibly represented by the equation,

monazite + calcic plagioclase + water $=$

$$
\text { allanite }+ \text { apatite }+ \text { thorite }+ \text { Ca-poorer plagioclase }
$$

In these studies, these striking textures (Figures $3 \mathrm{c}, \mathrm{d}$ ) have failed to progress to completion, probably limited by diffusion and possibly the availability of water. Their importance lies in the potential to date the retrogressive reaction by in situ isotopic techniques, and hypothetically, to determine P-T conditions of such reactions. Because little is known of the phase equilibria of the $\mathrm{CaO}-\mathrm{REE}-\mathrm{Phosphate}-\mathrm{ThO}-\mathrm{H}_{2} \mathrm{O}$ system in rocks, quantitative P-T-fluid conditions cannot be determined at present.

\section{Summary}

Notwithstanding the fact that most dating studies focus on determining protolith ages, the age of peak metamorphism, and/or the age of deformation events using magmatic 
rocks, there is much to be learned about the full temperature-time path and the response of rocks to reworking by the study of accessory minerals. Minerals other than zircon, namely allanite, monazite, titanite, and rutile often provide key information pertaining to the full thermal and metamorphic history of samples. This is possible because of their differential retention of radiogenic $\mathrm{Pb}$, their structural ability to withstand intense recrystallisation of the rock's matrix, and the nature of the $\mathrm{U}-\mathrm{Th}-\mathrm{Pb}$ isotope systematics. The understanding of the thermochemistry of mineral reactions involving accessory phases is in its infancy, but fascinating textures involving these minerals indicate that they are dynamically responding to changing environmental conditions during subsequent events. Careful study of complex samples can reveal both protolith crystallisation ages, protolith cooling ages, ages of the subsequent metamorphic-deformational event, and semi-quantitative information about the temperature and duration of subsequent events. The number of careful studies in this field is small at present, but is increasing steadily. The ability of accessory minerals and in some cases other rock forming minerals (micas) to record complexities of the chronology within a rock's reacting matrix ensures that fruitful research in this field will continue for years to come.

\section{Acknowledgements}

The author thanks T. Brewer, J. Crowley, J. Fraser, R. Simpson, and O. van Breemen for illustrations used in the text, and R. Holdsworth and J. Miller for the invitation to contribute to this volume. This work has been supported by NERC grant GR3/13006, NERC funding to the NERC Isotope Geosciences Laboratory, and Leicester University. 


\section{Figures}

1. Valhalla core complex thermal history, from Spear and Parrish (1996). The mineral chronometers used allow the reconstruction of the full cooling history of this high-grade terrain, with an average rate of cooling of about $25^{\circ} \mathrm{C} / \mathrm{Ma}$. Higher rates of short-lived cooling may have occurred immediately after reaching peak temperatures, possibly the result of thrust juxtaposition at deep crustal levels, as suggested by the dotted line. Fission track ages vary with altitude with a total range of nearly $20 \mathrm{Ma}$. Note that the temperature used for the $\mathrm{Rb}$-Sr muscovite age of ca. $55 \mathrm{Ma}$ is not the Rb-Sr muscovite closure temperature from Table 1, because the dated mica grew at lower greenschist facies metamorphic conditions (about $400^{\circ} \mathrm{C}$ ), well below the nominal $500^{\circ} \mathrm{C}$ closure temperature; this muscovite is therefore not a cooling age.

2. Photographs of Early Proterozoic structures re-worked by a Tertiary structuralmetamorphic event in British Columbia. (a) Folded gneissosity developed in 2.1 Ga orthogneiss and amphibolite, cut by foliated $2.05 \mathrm{Ga}$ amphibolite dyke, and then deformed during subsequent events at $1.85 \mathrm{Ga}$ and $50-60 \mathrm{Ma}$; hammer is 30 $\mathrm{cm}$ in length. (b) Folded and sheared ortho- and paragneisses of 1.86-2.2 Ga age that were subsequently deformed 50-60 Ma ago. A variety of structures can be discerned, the latest of which are about $50 \mathrm{Ma}$ old. The person standing is $1.6 \mathrm{~m}$ in height.

3. U-Pb concordia showing a summary of more than 50 analyses of zircon, monazite and titanite from rocks of the Monashee Complex of southeastern British Columbia, drawing on the work of Parrish (1995), Crowley (1999) and Crowley and Parrish (1999). The rocks dated consist of Early Proterozoic gneiss with a strong ca. $1.85 \mathrm{Ga}$ orogenic signature that were involved in a subsequent orogenic event under amphibolite facies conditions approximately 50-60 Ma ago. During the younger event the Monashee Complex footwall as overthrust by a thick allochthon (the Selkirk allochthon) undergoing uppermost amphibolite facies metamorphism, and this juxtaposition preserved inverted metamorphic isograds in the sheared footwall. Accessory minerals from Neoproterozoic gneisses of the footwall were disturbed by $\mathrm{Pb}$ loss and new mineral growth during the 50-60 Ma 
event, and the effect of this event was more intense at higher structural levels. In the figure, the field of analyses from the deeper structural levels are shown as the three larger patterned boxes with the least discordance. Note that titanite is more discordant than monazite. The highest grade of metamorphism in the footwall is just beneath the decollement and the analyses from these samples show much greater discordance and substantial new mineral growth. The discordance of minerals is likely the result of radiogenic $\mathrm{Pb}$ loss and/or new crystal growth onto an existing mineral. Studies of this type clearly demonstrate that the relative retentivity of $\mathrm{Pb}$ for monazite is higher than titanite.

4. Scanning electron micrographs of reaction textures involving accessory minerals. (a) back scattered electron microscope image of metamorphic zircon replacing baddeleyite $\left(\mathrm{ZrO}_{2}\right)$, in coronitic reaction textures within gabbroic rocks of the metamorphosed Sudbury dykes of Ontario (Davidson \& van Breemen 1988); (b) secondary electron image of rutile replaced by titanite 'buds' in the retrogressed eclogite from Glenelg, Scotland; note the similar morphology of these replacement grains to those of figure (a); (c) backscattered electron image of apatite and zoned allanite-epidote corona surrounding a core of monazite, evidence of monazite breakdown in schist in the Hunza region of northern Pakistan; (d) backscattered electron image of monazite breakdown reaction to produce a core of apatite + thorite (all monazite appears to have reacted, though some small relicts may be preserved in the bright central region), surrounded by REE-zoned allanite-epidote, also from Hunza, Pakistan; (e) secondary electron image of metamorphic zircon with round aspect, growing in retrogressed zone within eclogite, from near Glenelg, Scotland.

5. Microscopic images of external and internal morphologies of zircon from reworked gniessic rocks. Scale bar on all images are $100 \mu \mathrm{m}$. (a) secondary electron image of 55 Ma metamorphic zircon growing in the solid state in a metamorphised 740 Ma nepheline syenite gneiss from the Monashee Complex of British Columbia; (b) transmitted light image of highly irregular shapes of zircon from a recrystallised mylonite developed from a $100 \mathrm{Ma}$ hornblende-biotite grantoic protolith of the Valhalla Complex of southern British Columbia. The irregularity of the grains is predominantly the result of strong resorption of 
igneous grains, and comparison of some of these shapes to that of figure (e) indicates strong similarities; (c) secondary electron image of $50 \mathrm{Ma}$ anhedral metamorphic zircon grown in the solid state in a hornblende-plagioclase amphibolite of probable Late Palaeozoic age, with multiple planar growth faces that do not clearly correspond to crystallographic faces; southern British Columbia; (d) secondary electron image of moderately resorbed subhedral zircon with significant metamorphically-induced rounding of crystal faces, Valhalla Complex of southern British Columbia; (e) backscattered electron image of etched internal surface of highly resorbed Early Proterozoic zircon from ca.1.95 Ga granulite facies Thelon tectonic zone of the northwest Canadian Shield. The $>2.0$ Ga core is overgrown by new zircon of ca. $1.95 \mathrm{Ga}$ age; note the overall round shape masking the internal complexity and evidence of strong resorption; (f) backscattered electron image of composite granulite facies zircon from mylonitic straight gneiss of the Thelon zone, northwest Canadian Shield; the resorbed $>2.0$ Ga core is overgrown by a complex region of wedge-shaped growth zones, most of which are in turn truncated and overgrown by new zones, resembling 'crossstratification; this may have been produced by repeated dissolution and precipitation of zircon rotating in the rock fabric during shearing, exposing sides of the crystal to differential chemical and strain gradients during rotation.

6. U-Pb concordia diagram of zircon, allanite and titanite from granitic rocks reworked by subsequent upper amphibolite facies heating and recrystallisation. These samples are from the metamorphic core zone of southeast British Columbia, including the Selkirk Allochthon and Valhalla Complex. (a) the 100 Ma Mulvey gneiss of the Valhalla Complex (Spear \& Parrish 1995) with clear separation of zircon, allanite, and titanite analyses illustrating variable $\mathrm{Pb}$ loss; (b) similar pattern of discordance within Devonian orthogneiss of the Selkirk Allochthon (see Heaman \& Parrish 1991). Both samples were thoroughly recrystallised at ca. 60 Ma during metamorphism and deformation. Although experiencing some resorption and new crystal growth, the accessory minerals preserve some of the isotopic signature of the protolith, indicating that $\mathrm{Pb}$ loss was not complete. This proves that allanite and titanite did not undergo the thorough recystallisation experienced by the matrix minerals. 
References

Armstrong, R. L. 1966. K-Ar dating of plutonic and volcanic rocks in orogenic belts. In: Schaeffer, O. A. \& Zahringer, J. (eds) Potassium-Argon Dating. SpringerVerlag, New York, 117-133.

Bowring, S. A. \& Williams, I. S. 1999. Priscoan (4.00 Ga) orthogneisses from northwestern Canada. Contributions to Mineralogy and Petrology, 134, 3-16.

Carslaw, H. S. \& Jaeger, J. C. 1959. Conduction of Heat in Solids, $2^{\text {nd }}$ ed. Clarendon, Oxford, $510 \mathrm{pp}$.

Cherniak, D. J. 1993. Lead diffusion in titanite and preliminary results on the effects of radiation damage on $\mathrm{Pb}$ transport. Chemical Geology, 110, 177-194.

Compston, W., Williams, I. \& Meyer, C. 1984. U-Pb geochronology of zircons from lunar breccia 73217 using a sensitive high mass-resolution ion microprobe. Journal of Geophysical Research, 89B, 525-534.

Crowley, J. L. 1999. U-Pb geochronologic constraints on Paleoproterozoic tectonism in the Monashee complex, Canadian Cordillera: elucidating an overprinted geologic history. Geological Society of America Bulletin, 111, 560-577.

Crowley, J. L. \& Parrish, R. R. 1999. U-Pb isotopic constraints on diachronous metamorphism in the northern Monashee complex, southern Canadian Cordillera. Journal of Metamorphic Geology, 17, 483-502.

Davidson, A., \& van Breemen, O. 1988. Baddeleyite-zircon relationships in coronitic metagabbro, Grenville Province, Ontario: implications for geochronology. Contributions to Mineralogy and Petrology, 100, 291-299. 
Dewey, J. F., Ryan, P. D. \& Andersen, T. B. 1993. Orogenic uplift and collapse, crustal thickness, fabrics and metamorphic phase changes: the role of eclogites. In: Alabaster, H. M., Harris, N. B. W. \& Neary, C. R. (eds) Magmatic Processes and Plate Tectonics. Geological Society, London, Special Publications, 76, 325-343.

Dodson, M. H. 1973.Closure temperatures in cooling geochronological and petrological systems. Contributions to Mineralogy and Petrology, 40, 259-274.

Finger, F., Broska, I., Roberts, M. P. \& Schermaier, A. 1998. Replacement of primary monazite by apatite-allanite-epidote coronas in an amphibolite facies granite gneiss from the eastern Alps. American Mineralogist, 83, 248-258.

Fraser, J. E. 2000. The structural and metamorphic evolution of the deep crust in the Hunza Karakoram, north Pakistan. DPhil thesis, Oxford.

Freeman, S. R., Inger, S., Butler, R. W. H. \& Cliff, R.A. 1997. Dating deformation using $\mathrm{Rb}$-Sr in white micas: greenschist facies deformation ages for the Enterlor Shear Zone, Italian Alps. Tectonics, 16, 57-76.

Gee, D. G. 1978. Nappe displacement in the Scandinavian Caledonides. Tectonophysics, 47, 393-419.

Harrison, T. M. 1981. Diffusion of ${ }^{40} \mathrm{Ar}$ in hornblende. Contributions to Mineralogy and Petrology, 78, 324-331.

Harrison, T. M., Duncan, I., \& McDougall, I. 1985. Diffusion of ${ }^{40} \mathrm{Ar}$ in biotite: Temperature, pressure and compositional effects. Geochimica Cosmochimica Acta, 49, 2461-2468. 
Hart, S. R. 1964. The petrology and isotopic-mineral age relations of a contact zone in the Front Range, Colorado. Journal of Geology, 72, pp. 493-525.

Heaman, L. \& Parrish, R. R. 1991. U-Pb geochronology of accessory minerals. In: Heaman, L. \& Ludden, J. N. (eds) Applications of Radiogenic Isotope Systems to Problems in Geology. Mineralogical Association of Canada, Short Course Handbook, 19, 59-102.

Jäger, E., Niggli, E., \& Wenk, E. 1967. Rb-Sr Altersbestimmungen an Glimmern der Zentralalpen. Beiträge zur Geologischen Karte der Schweiz, 134.

Krabbendam, M. \& Dewey, J. F. 1998. Exhumation of UHP rocks by transtension in the Western Gneiss Region, Scandinavian Caledonides. In: Holdsworth, R. E., Strachan, R. A. \& Dewey, J. F. (eds) Continental Transpressional and Transtensional Tectonics. Geological Society, London, Special Publications, 135, $159-181$

Lee, J. K. W., Williams, I. S. \& Ellis, D. J. 1997. Pb, U and Th diffusion in natural zircon. Nature, 390, 159-162.

Lucas, S. \& St-Onge, M. 1992. Terrane accretion in the internal zone of the Ungava orogen, northern Quebec. Part 2: Structural and metamorphic history. Canadian Journal of Earth Sciences, 29, 765-782.

McDougal, I. \& Harrison, T. M., 1988. Geochronology and Thermochronology by the ${ }^{40} \mathrm{Ar} /{ }^{39} \mathrm{Ar}$ method. Oxford Monographs on Geology and Geophysics, 9. 
Meffan-Main, S. \& Cliff, R. A. 1997. Reliable dating of metamorphic fabrics in Alpine basement rocks using Rb-Sr microsampling. Terra Nova 9, Abstract supplement 1, 486-487.

Mezger, K., Hanson, G. N., \& Bohlen, S. R. 1989. High-precision U-Pb ages of metamorphic rutile: application to the cooling history of high-grade terranes. Earth and Planetary Science Letters, 96, 106-118.

Naeser, C. W. 1979. Fission track dating and geological annealing of fission tracks. In Jager, E. \& Hunziker, J. C. (eds) Lectures in Isotope Geology. Springer-Verlag, New York, 154-169.

Parrish, R. R., 1995. Thermal and tectonic evolution of the southeastern Canadian Cordillera, Canadian Journal of Earth Sciences, 32, 1618-1642.

Parrish, R. R., Carr, S. C. \& Parkinson, D. 1988. Eocene extensional tectonics and geochronology of the southern Omineca belt, British Columbia and Washington. Tectonics, 7, 181-212.

Piasecki, M. A. J. \& van Breemen, O. 1983. Field and isotopic evidence for a c.750 Ma tectonothermal event in Moine rocks in the Central Highland region of the Scottish Caledonides. Transactions of the Royal Society of Edinburgh: Earth Sciences, 73, 119-134.

Purdy, J. W. \& Jäger, E.1976. K-Ar ages on rock-forming minerals from the Central Alps. Memoirs, 30: 1-31, Institute of Geology and Mineralogy, University of Padova. 
Sanders, I. S., van Calsteren, P. W. C. \& Hawkesworth, C. J. 1984. A Grenville SmNd age for the Glenelg eclogite in north-west Scotland. Nature, 312, 439-440.

Scott, D. J \& St-Onge, M. 1995. Constraints on $\mathrm{Pb}$ closure temperature in titanite based on rocks from the Ungava orogen, Canada: Implications for U-Pb geochronology and P-T-t path determinations. Geology, 23, 1123-1126.

Simpson, R. L., Parrish, R. R., Searle, M. P. \& Waters, D. J. 2000. Two episodes of monazite crystallisation during prograde metamorphism and crustal melting in the Everest region of the Nepalese Himalaya. Geology, 28, 403-406.

Smith, H. A. \& Giletti, B. J. 1997. Lead diffusion in monazite. Geochimica et Cosmochimica Acta, 61, 1047-1055.

Spear, F., \& Parrish, R. R., 1996. P-T-t evolution of the Valhalla Complex, British Columbia, Canada. Journal of Petrology, 37, 733-765.

Stern, R. A. 1999. In situ analysis of radiogenic isotopes with emphasis on ion microprobe techniques and applications. In Lambert, D.D. \& Ruiz, J. (eds) Application of radiogenic isotopes to ore deposit research and exploration. Reviews in Economic Geology, 12, 173-199.

St-Onge, M. R., Lucas, S. B., \& Parrish, R. R., 1992. Terrane accretion in the internal zone of the Ungava orogen, northern Quebec. Part 1: Tectonostratigraphic assemblages and their tectonic implications. Canadian Journal of Earth Sciences, 29, 746-764. 
Suzuki, K, Adachi, M, \& I Kajizuka. 1994. Electron microprobe observations of Pb diffusion in metamorphosed detrital monazites. Earth and Planetary Science Letters, 81, 203-211.

Tucker, R. D., Råheim, A., Krogh, T. E. \& Corfu, F. 1987. Uranium-lead zircon and titanite ages from the northern portion of the Western Gneiss Region, south-central Norway. Earth and Planetary Science Letters, 81, 203-211.

Wain, A. 1997. New coesite-eclogite occurrences in western Norway: the nature of an ultrahigh pressure province in the Western Gneiss Region. Geology, 25, 927-930.

Wayne, D. M. \& Sinha, A. K. 1988. Physical and chemical response of zircons to deformation. Contributions to Mineralogy and Petrology, 98, 109-121.

Wayne, D. M. \& Sinha, A. K. 1992. Stability of zircon U-Pb systematics in a greenschist grade mylonite: An example from the Rockfish Valley fault zone, central Virginia, USA. Journal of Geology 100, 593-603.

Zhu, X. K., O’Nions, R. K., Belshaw, N. S. \& Gibb, A. J. 1997. Lewisian crustal history from in situ SIMS mineral chronometry and related metamorphic textures. Chemical Geology, 136, 205-218.

Zhu, X. K. \& O’Nions, R. K. 1999. Zonation of monazite in metamorphic rocks and its implictions for high temperature thermochronology: a case study from the Lewisian terrain. Earth and Planetary Science Letters, 171, 209-220. 
Table 1. Mineral isotopic closure temperatures

\begin{tabular}{|l|c|l|}
\hline Mineral & Closure temperature & Reference \\
\hline U-Th-Pb zircon & $>900^{\circ} \mathrm{C}$ & Lee et al. (1997) \\
\hline U-Th-Pb monazite & $>750^{\circ} \mathrm{C}$ & Spear and Parrish (1996) \\
\hline U-Pb xenotime & $>650^{\circ} \mathrm{C}(?)$ & Heaman and Parrish (1991) \\
\hline U-Th-Pb allanite & $650^{\circ} \mathrm{C}$ & Heaman and Parrish (1991) \\
\hline $\begin{array}{l}\text { U-Th-Pb titanite } \\
\text { U-Pb rutile }\end{array}$ & $600^{\circ} \mathrm{C}$ & Heaman and Parrish (1991), Cherniak (1993) \\
\hline $\begin{array}{l}\mathrm{K}-\mathrm{Ar},{ }^{39} \mathrm{Ar}-{ }^{40} \mathrm{Ar} \\
\text { hornblende }\end{array}$ & $500^{\circ} \mathrm{C}$ & Mezger et al. (1989) \\
\hline $\begin{array}{l}\text { Rb-Sr muscovite } \\
\text { Kb }\end{array}$ & $500^{\circ} \mathrm{C}$ & $\begin{array}{l}\text { Harrison (1981); MacDougall and Harrison } \\
(1988)\end{array}$ \\
\hline $\begin{array}{l}\text { K-Ar, }{ }^{39} \mathrm{Ar}-{ }^{40} \mathrm{Ar} \\
\text { muscovite }\end{array}$ & $350^{\circ} \mathrm{C}$ & Purdy and Jäger (1976) \\
\hline $\begin{array}{l}\mathrm{K}-\mathrm{Ar},{ }^{39} \mathrm{Ar}-{ }^{40} \mathrm{Ar} \\
\text { biotite }\end{array}$ & $280 \pm 40^{\circ} \mathrm{C}$ & Harrison et al. (1985) \\
\hline $\begin{array}{l}\text { Fission } \mathrm{Track} \\
\text { apatite }\end{array}$ & $100-120^{\circ} \mathrm{C}$ & Naeser (1979) \\
\hline
\end{tabular}




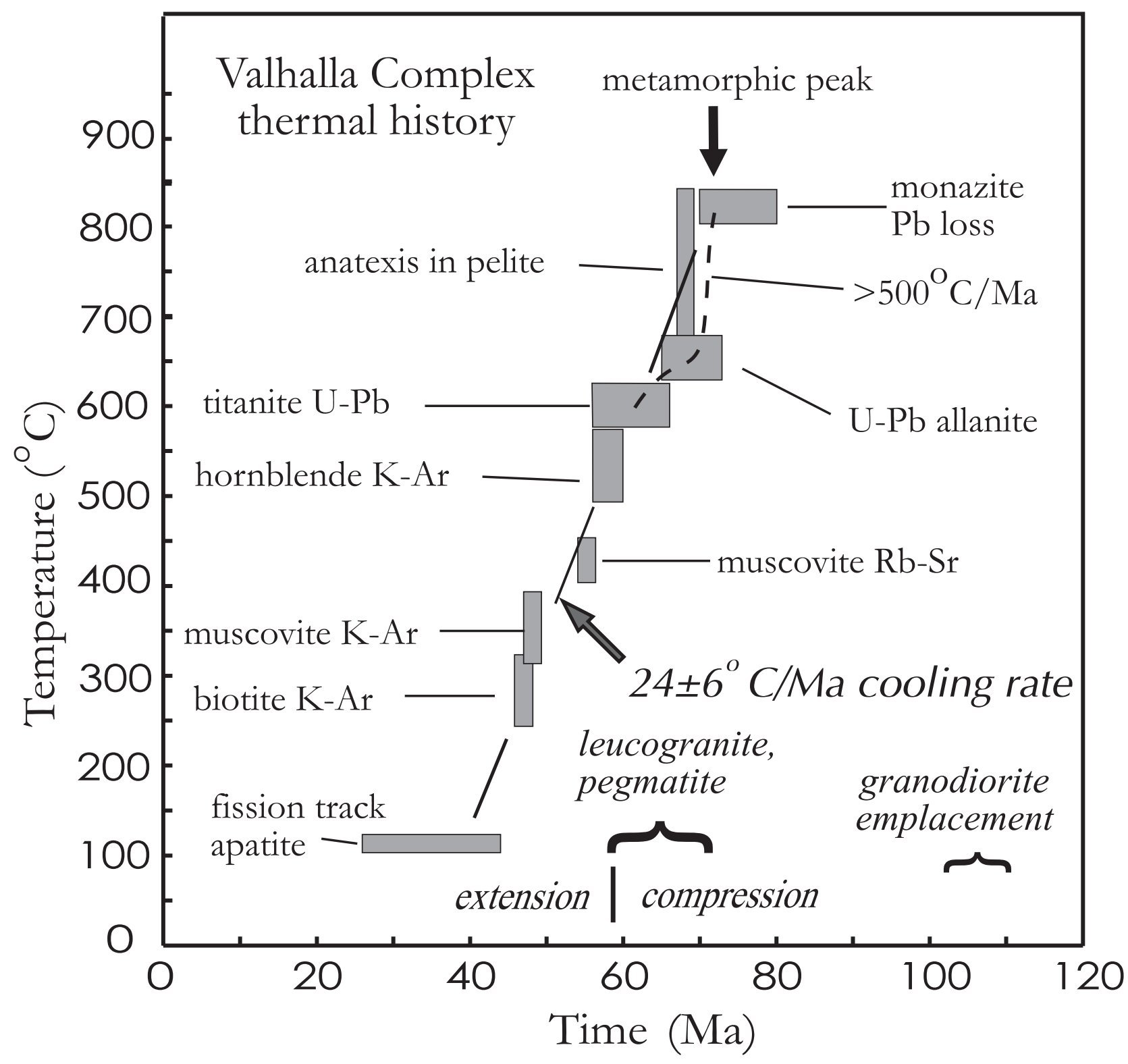

Figure 1 


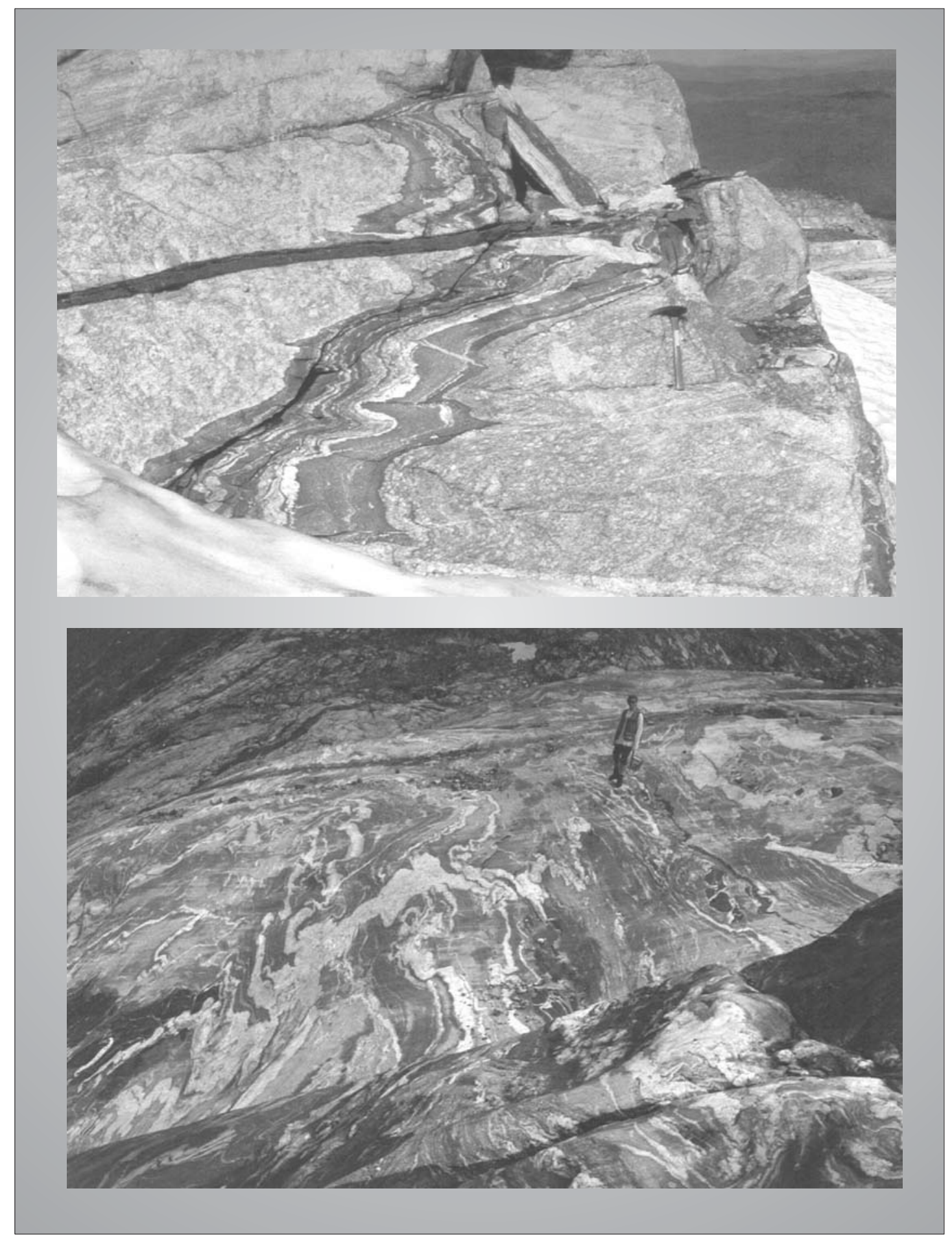

Figure 2. 


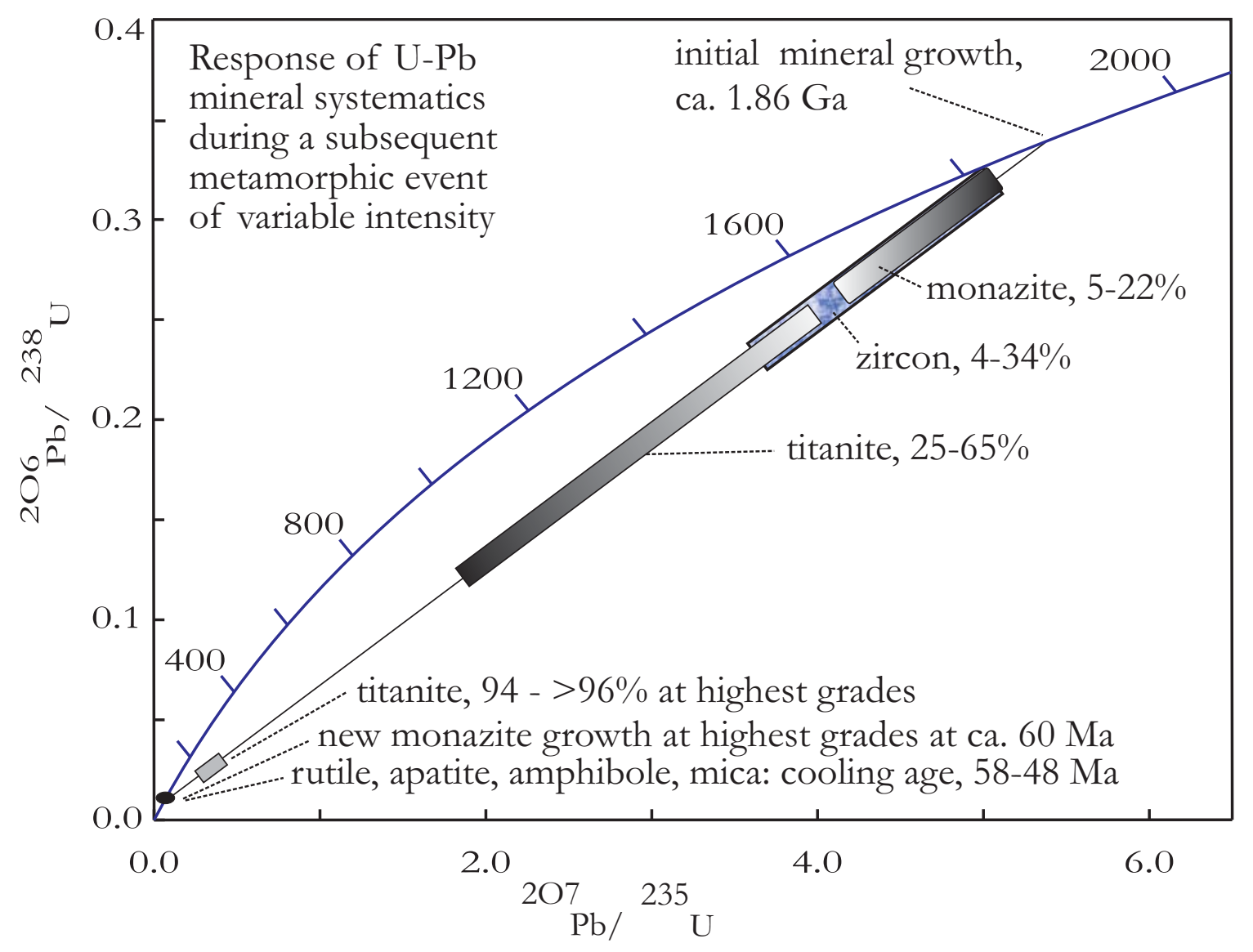

Fig 3 

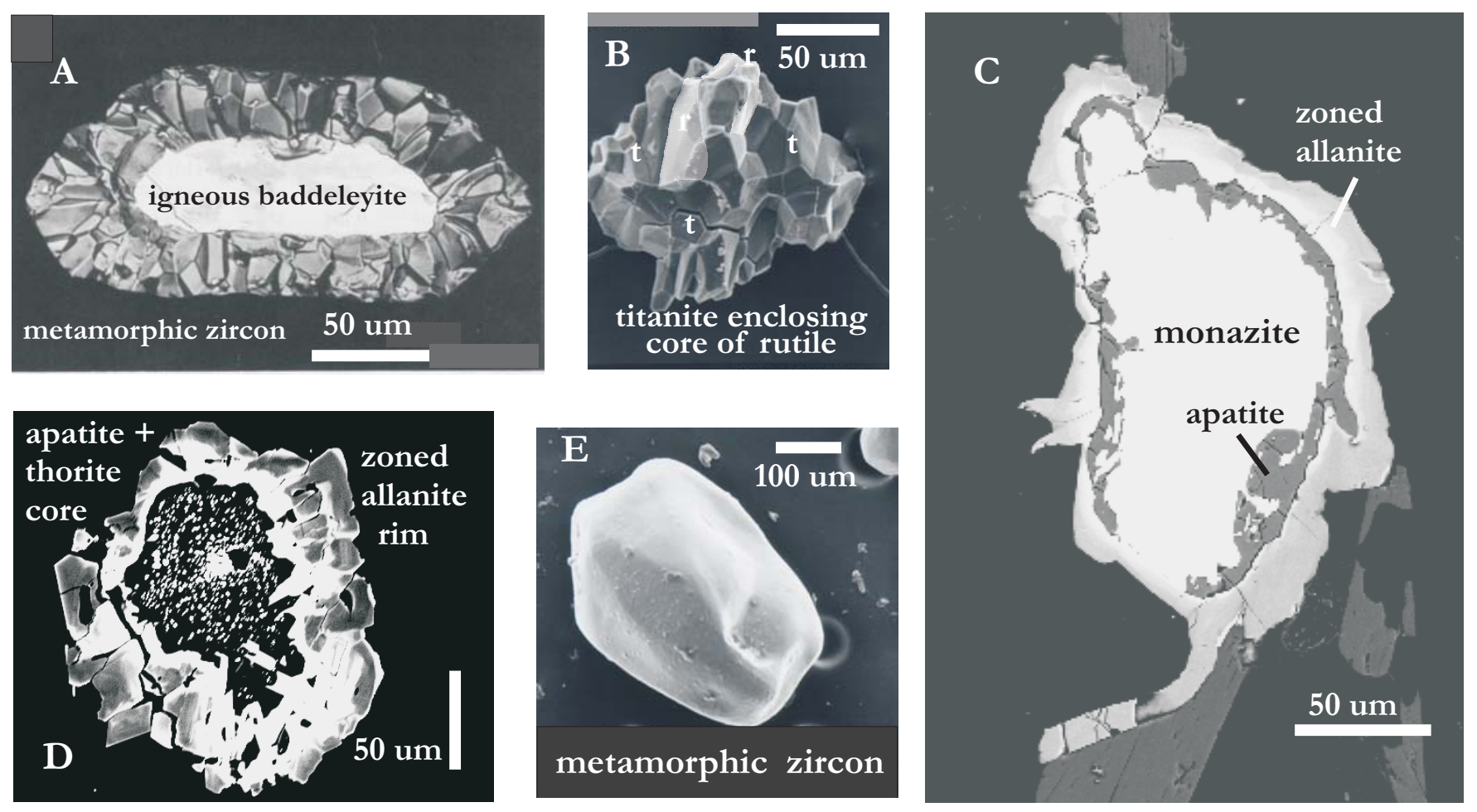

Figure 4 


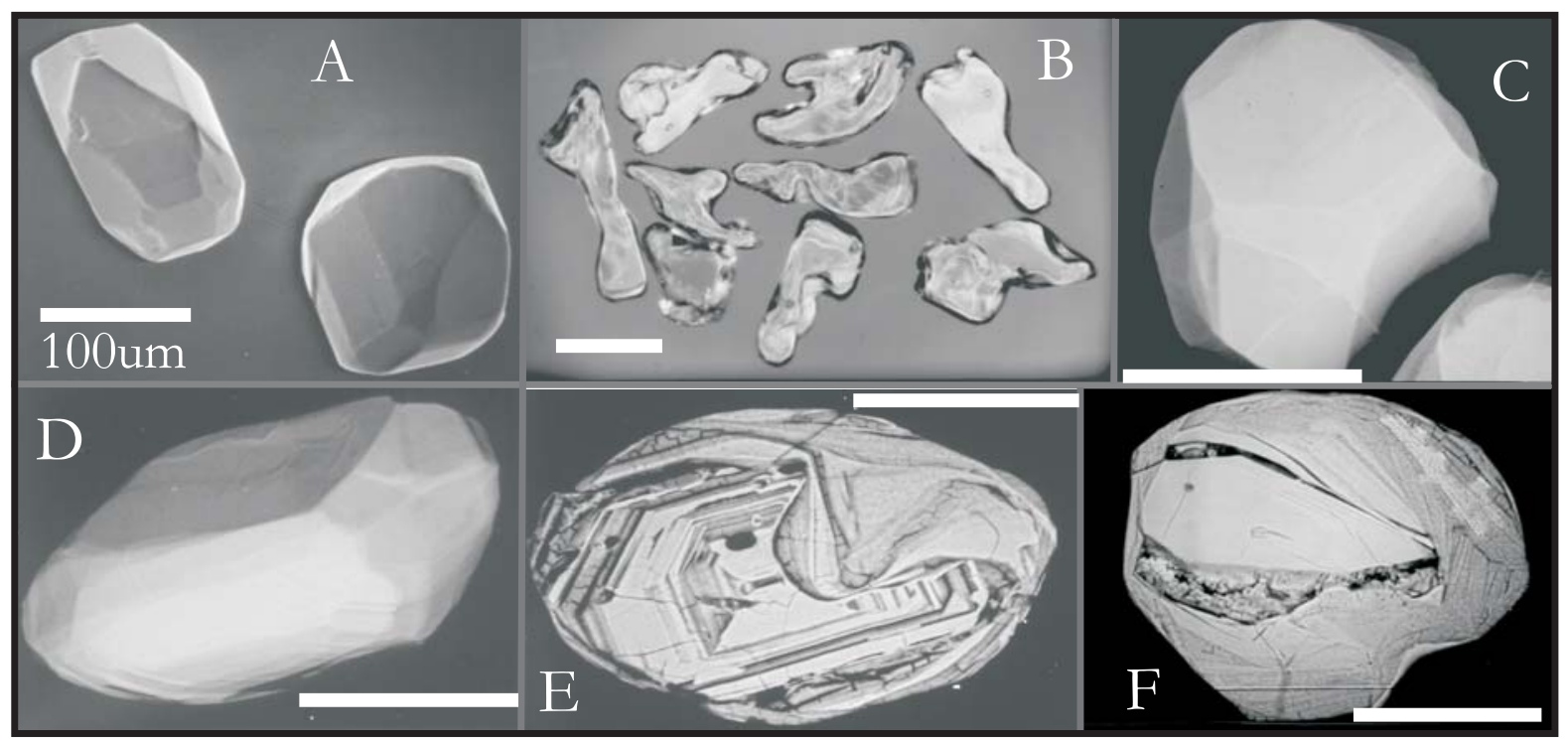

Figure 5 

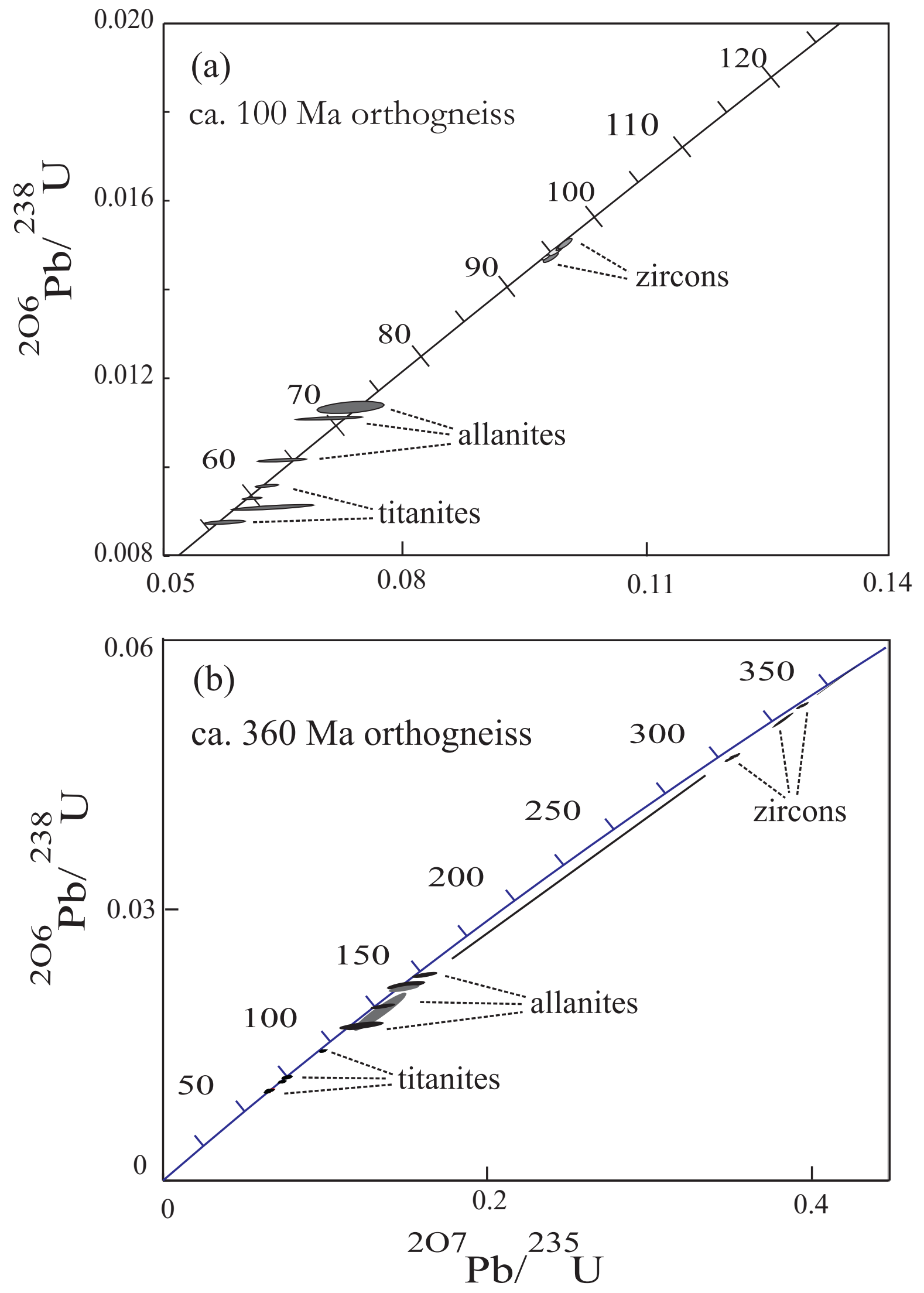

Fig 6 